\title{
Adoption of Information and Communication Technology (ICT) in Management of Information Resource and Service in National Eye Centre Research Library, Kaduna
}

\author{
Usman Mu'azu
}

\author{
Kashim Ibrahim Library \\ Ahmadu Bello University, Zaria
}

\author{
Doi:10.5901/jesr.2014.v4n7p48
}

\begin{abstract}
The study was conduction to determine the Adaption of information and communication technology (ICT) in management center of information and service resources and service in Eye centre research library, Katsina. A case study research method was adopted for this research and the data for the investigation were derived through the use of questionnaire observation and interview figures derive from the data were expressed in frequency and percentage and tables were uses to enhance comparism of data. The findings revealed that ICT affects the management of information resource through analysis of users needs, through inter and inter-library communication resource through e-mail cell phones and slides/slides projector, Also the library provided service such as internet service, email a fax simile (fax) machine, photocopying, online information service , and management information services. The finding also revealed the problem or challenge in the application of ICT resources this includes: funds personal, power supply software, hardware network ICT. Resource in the library on the basis of findings, conclusions were made for the improvement of management (ICT) resources and services in eye centre research library.
\end{abstract}

\section{Introduction}

The use of information and communication technology (ICT) is an important aspect that is every organization in a variety of ways. It alters the skills requirement for individual and it changes jobs and the way they are done. It also alters relationship with customer, suppliers and clients outside the organization. It is the major factors in determining the type of information available and how the information is us and consequently how the organization operates.

The use of information in National Eye Centre cannot be effective without the adoption of ICT in every department. ICT is the phrase use to decrease a range of technologies for gathering, storing, retrieving, processing analysis and transmitting information. It input, process, and transfer data and output of information. It also enables e-knowledge and the invention of e-knowledge processing. It uses technology for business development, to process information and aid communications.

There are enormous amount of data available to managers generated both internally and externally. It is impossible to deals with this volume of data without information technology.

Therefore, the adoption of ICT in various departments of NEC will go a long way in influencing its mandate in providing a comprehensive health care. Service training and research facilities for ophthalmologists, orthoptists, ophthalmic Nurse and all cadres of Eye Health Manpower.Library and information services and objectives of NEC.

Library is a store house of information it consist of books and non-book materials. According to encyclopedia of library and information science (1980:3.5), "a library is an organization, a system designed to preserve and facilitate the use of graphic records. It is a social and research instrument creative to for a link in the communication system that is essential to any society or culture.

Furthermore, libraries and information services are highly dependants upon reprographic and communication facilities. Al most every library form a larger organization, a small business, laboratory research organization, or an academic institution. Each library usually provides services as to its parent organization, and the employees of that organization, or to a specific user group. For example NEC library provides services for those who live/or work within the organization.

\subsection{Statement of The Problems}

The National Eye Centre (NEC) Kaduna is a parastatal of the federal ministry of health. The Hospital was established 
under Decree 52 of 1979 by the Murtala/Obasanjo Government, the Decree mandates the centre to provide comprehensive ophthalmic services, training and research. The centre was commissioned on $21^{\text {st }}$ December, 1992 but the clinical activities took off progressively in 1993. More units were established during the year to cater for the increased clinical activities in the centre. For effective operation and the committee (TMC), the board members, heads of departments units always meet to appropriately formulate policies, tackle issues in order to attain the required medical and administration services delivery.

Being the apex in ophthalmology in the country, and indeed the West African sub-region, the chief Executive of the NEC remains the vice chairman of the National program for the prevention of blindness (NPPB), which has its Headquarter at the federal ministry of Health Abuja. They also make collaborative effort with world Health organization (WHO), orbits international sight savers international etc for excellence services delivery. The Hospital vision is to be a leading eye care provider in Africa. While the mission is to reduce blindness in Nigeria through the provision of comprehensive eye care services, training, education, research and policy advocacy (NEC) is also known as National institute of ophthalmology (NIO). NEC has a medical or research library which stocks relevant books and volumes of journals both on foreign and local in ophthalmology and its related fields. It also stocks books of general interest in management, accounting, engineering and nursing education, the library organized, planned and administered audio visual services program. The library has six operational units and they includes:
$>$ Information and Data Bank unit
$>$ Technical unit
Circulation unit
$>$ The administration unit and
$>$ Serial unit

\subsection{Information Technology (It) Unit}

The library is connected to the internet with ten computers with IT staff to manage it and there are some of the ICT resources like CD-ROM, slides, computer network, binding machines, photocopier machine, compact disk etc and the library is fully air conditioned. The establishment of the library is aim at meeting the clinical, training, and research need of the hospital and users, provide research facilities for the development of ophthalmology, and specialized in information services, to achieve the goals and objectives of the hospital.

National eye centre has an information technology (IT) unit and enough IT analysts. The unit was established in 2006 and part of the unit is set up in the library for internet access in order to provide more approaches as to research, teaching and learning to follow the current trends of development and to add to library resources. But the problems militating ICT presently that resulted to in accessibility of internet in research library could be attributed to lack of subscription, lack of funds to run the ICT, or it could be that the equipments are not functioning or underutilized and could also be due to lack of enough or inadequate equipment to access the internet and lastly could be due to epileptic power supply. It is against this background that the researcher intends to find out the reason why ICT resources adopted, is not functioning in NEC library the way it should be following the new trend in technology and the way of adopting ICT management of information resources and services.

\subsection{Research Questions}

1. How does ICT affect the management of information resources?

2. What types of ICT facilities are available for managing information resources?

3. How is ICT used to access information by the staff?

\subsection{Objectives of The Study}

1. Find out how ICT affects the managements of information resources.

2. To identify types ICT facilities, available for managing information services

3. To find out how ICT is used to access information by the staff. 


\section{Methodology}

\subsection{Introduction}

This study describes the method and procedures used in gathering data. It describe the research method adopted, the population of the instrument used for collecting data, procedure for collecting data, and the method of analyzing data obtained.

\subsection{Research Method Adopted}

The research method used for this study is a case study the research involves the gathering of data on the adoption of ICT in management of information resources and services in NEC research library. NEC is a single unit that needs to be examined. According to Suleiman (2007), "case study usually refers to a fair intensive examination of a single unit such as a person, a small group of people or indeed a single company." It enables research to explore, unravel, understood problems, issues and relationships.

\subsection{Population of the Study}

The population consists of staff of national eye centre Kaduna. Those that constitute the target population are chief librarian, IT staff, Doctors and Nurses. The factual figure of the general number constitute the study population is a total of 471 while the number constituting the target population for this study id 50 .

Instrument used for collecting data. The instruments of data collection for this study are observation, interview and questionnaires.

From the above, the response rate show that all the total number of the questionnaires distributed which is 50 returned. And the number of the questionnaire collected to various occupations of respondents are: Doctor 20, questionnaire was distributed and same number of 20 questionnaires was collected is $40 \%$ Nurse 16 questionnaires was distributed and same 16 was collected making $32 \%$ of the respondents. IT staff 8 questionnaires distributed to them and the same number was collected which is $16 \%$ while library staff were given 6 questionnaires and the same 6 was returned which is $12 \%$. However, the finding revealed that all the questionnaires distributed to the respondents above were returned or collected. This shows that the respondents responded well to researchers finding.

Management of information resources and services

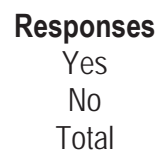

Frequency
49
1
50

Percentage (\%)
98
2
100

\section{Data Analysis}

\subsection{Introduction}

This study gives the presentation, analysis and discussion if finding from the respondents. The analysis mainly focus on research questions of this study which sought to find answers to the adoption of information and communication Technology (ICT) in management of information Resources and services in National Eye Centre (NEC) Research library, Kaduna.

\subsection{Response Rate}

The research work tried to analyze the data collected through oral interviewed from respondents, according to their subject heading in the questionnaire, were distributed to some staff of NEC. 


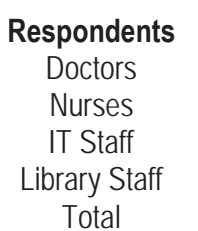

No of questionnaires
20
16
8
6
50

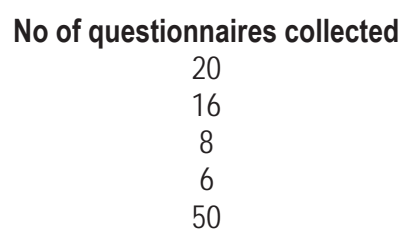

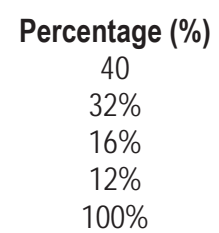

From the above table, it shows that $98 \%$ respondents agreed that adoption of ICT has brought changes in the management of information resources services while only $2 \%$ that represent (1) respondent is of the opinion that ICT has not brought changes to management of information resources and services.

Table 2a: if yes how has ICT brought changes

Responses
Easy access to information
Easy storage up information
Reduce fatigue
Information. Dissemination
Saves time
Evidence of manual skill
Total

$\begin{array}{cc}\text { Frequency } & \text { Percentage (\%) } \\ 19 & 38 \\ 15 & 30 \\ 5 & 10 \\ 2 & 4 \\ 8 & 16 \\ 1 & 2 \\ 50 & 100\end{array}$

The table above, shows that $38 \%$ of the respondent see that changes ICT has brought to NEC as easy access to information, $10 \%$ feel that ICT reduce work fatigue, while only 4 see changes to be information dissemination, $16 \%$ also agree that ICT has helped in saving time, while only $2 \%$ believe that ICT has brought no changes since manual skill is still evident.

Table 3: ICT in management of information Resources and Services

Table 3: Effect of ICT management of information Resource and services

Responses
Easy retrieval of infor.
Provide universal access
Provide knowledge managt
Provide efficient services
Any other
Total

Frequency
22
12
6
10
All of the above
50

Percentage (\%)
44
24
12
20
All of the above
$100 \%$

The types of ICT facilities available for information resource in librarcy

Responses
Computer network
Digital radio
Television
Wireless phone
CD-Rom
Electronic mail(email)
Cell phone
Slide projector
Total

Frequency
29
1
4
5
6
3
2
-
50

Percentage (\%)
$58(\%)$
$2(\%)$
$8(\%)$
$10(\%)$
$12(\%)$
$6(\%)$
$4(\%)$
$0(\%)$
$100(\%)$

The above table reveal the $50 \%$ responded that the types of ICT facilities available for managing library is computer network,20 that represent (1) respondent assumed that digital radio is one of the ICT facilities available in library ,8\% responded that the library has TV as one of the types of ICT resources 10\% agree that the library has wireless phone,12\% of the respondents shows that there is C.D-Rom mail) as one of the ICT facilities available in the library then $4 \%$ also responded that there is cell phones and lastly, none of the respondent agreed that there is slide/slide projection as one of the types of ICT facilities available for managing information resources in research library. This shows that (29) 
i.e. 58\% has the highest respondents to computer network as the types of ICT facility available for managing information resource in NEC research library.

How ICT is used to access information in NEC research library

Responses
Facsimile fax machine
Telephone
internet
Data base
E-mail
Total

$\begin{array}{cc}\text { Frequency } & \text { Percentage (\%) } \\ 2 & 4 \% \\ 6 & 12 \% \\ 20 & 40 \% \\ 12 & 24 \% \\ 10 & 20 \% \\ 50 & 100 \%\end{array}$

According to the finding of the research above the use of ICT to access information in NEC research library, $4 \%$ respondent shows that facsimile (fax) machine is used to access information 12\% were for telephone, $40 \%$ for internet which is the highest respondents followed by $24 \%$ database used to access information and 20 agreed that email is used to access information while there was no respondent for any other access to information.

This shows that many used internet which is the highest number of respondents to access information.

\section{Findings}

1. The findings revealed that ICT affected the management of information resource through analysis of users need through inter and inter-library communication and through email.

2. The findings shows that the types of ICT facilities available for managing information are computer networks, digital radio television , wireless phones CD-Rom, electronic mail(email), cell phones and slide/slides projector.

3. Findings prove that, research library provides access to information using ICT are through facsimile (fax) machine, telephone internet, data base and e-mail.

\section{Conclusion}

Base on the findings of this study and the interpretation of base of data, of the adoption of information and communication technology (ICT) in management of information resources and services revealed some important point about the adoption of ICT resources they are: the retrieval of information, the storage of information, types of services rendered and the challenges.

\section{Recommendation}

1. The management of national eye centre, should introduce solar panel/invertors or a generator set to power ICT resource adequately in the library in case of power failure

2. Adequate funds for provision of more quality computer hardware adequately in the library in case of and maintainers of ICT resources in the library.

\section{References}

British medical association (1987:1), Medical librancies a user glinder London: The British medical association. pp I

DAVID, Skyrme (1994) "Management information"Vol.1 No.3

DANIEL, Emojorlo (2011), "library philosophy" and practices" Nigeria

HARROD, L.M (1938) "The librarian" Glossary" Greet Britain, Grafton \&C.O pp.283 285,420

ISSA, A.O (2004). Practical cinder to project writing for student polytechnics, colleges and universities" Nigeria

JACOB, Sunday (2005) A practical grinder to project for students in tertiary institution

Library Association (1986:5-6) the impact of new technology on libraries and information centre: reports of the library association working, party 1981-82 British library.

National Eyes Center Kaduna (2008) Annual report January to December, "World health organization collaborating center for prevention of Blindness. 